\title{
"Buellia" lindingeri and Rinodina hallii (Physciaceae), two closely related species
}

\author{
Mireia Giralt ${ }^{1,4}$, Pieter P. G. Van den Boom ${ }^{2}$, and John A. Elix ${ }^{3}$
}

${ }^{1}$ Departament de Bioquímica i Biotecnologia (Àrea de Botànica), Facultat d'Enologia de Tarragona, Universitat Rovira i Virgili, Marcel·lí Domingo s/n, 43007, Tarragona, Spain; ${ }^{2}$ Arafura 16, 5691 JA, Son, The Netherlands; ${ }^{3}$ Research School of

Chemistry, Building 33, Australian National University, Canberra, ACT 0200, Australia

\begin{abstract}
Aвstract. A comparative study of the morphology, anatomy and chemistry of Buellia lindingeri and Rinodina hallii clearly shows that these taxa are very closely related but not conspecific. The unique epihymenia distinguishes them from most species of both Buellia and Rinodina but, as they are more closely related to Rinodina, Buellia lindingeri is transferred to that genus.
\end{abstract}

KeYwords. Macaronesia, North America, lichenized ascomycetes, morphology, chemistry, taxonomy, new combination.

While compiling information on Rinodina from the Canary Islands (Boom van den et al. 2009), we were surprised to find the North American species Rinodina hallii Tuck. included in the Canarian checklists (Hafellner 1995, 2002, 2005; HernándezPadrón 2001). This species is reported from El Hierro (Hernández-Padrón 1987), growing on the cortex and lignum of Juniperus phoenicea, but, unfortunately, the material in TFMC was not available for study (Hernández-Padrón pers. comm.). After studying the description given by Hernández-Padrón (1987), we suspected that the specimens were, in fact, referable to Buellia lindingeri Erichsen, a rather common and widely distributed species in Macaronesia. Moreover, a comparison of the diagnosis and additional descriptions of $B$. lindingeri and R. hallii (Giralt \& Matzer 1994; Magnusson 1947;

$\overline{{ }^{4} \text { Corresponding author e-mail: mireia.giralt@urv.cat }}$ DOI: 10.1639/0007-2745-113.1.99
Sheard 2004), indicated that these taxa were morphologically very similar. As a consequence, we performed a comparative study of the two species. The results have shown that they are closely related, with many morphological and chemical characters in common, but not conspecific. Further, both species have an almost plectenchymatic epihymenium (= epithecium) and seem to occupy an isolated position within both Buellia s. lat. and Rinodina. However, as they are most closely related to Rinodina, B. lindingeri is transferred to that genus.

\section{Materials and Methods}

This study was based on herbarium material from $\mathrm{ASU}, \mathrm{BCN}, \mathrm{FH}$ and from the private herbaria of $\mathrm{M}$. Brand and P. van den Boom. Lichen morphology was examined by standard techniques using stereo and compound microscopes. The terminology used for the apothecia follows Dughi (1952) and Giralt (2001), for the asci that of Rambold et al. (1994) and 


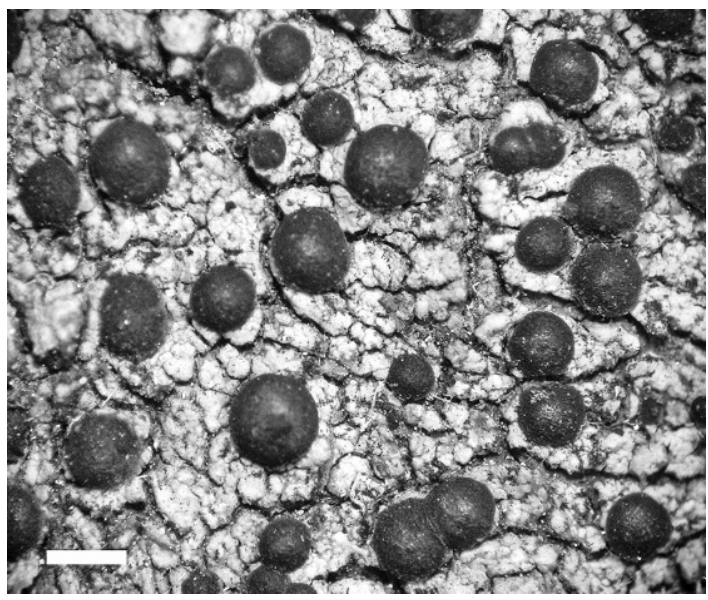

Figure 1. Thallus rimose-areolate with adnate, lecideine apothecia with excluded proper margins and convex discs of Rinodina hallii (FH lectotype). Scale $=1 \mathrm{~mm}$.

for the ascospore-type and ontogeny that of Giralt (2001). Chemical constituents were identified by high performance liquid chromatography (HPLC) (Elix et al. 2003).

\section{The SpeCIES}

Rinodina hallii Tuck., Bull. Torrey Bot. Club 5: 20. 1874. Type: U.S.A.. OREgON: upon bark, 1871, E. Hall (FH-259425!; lectotype, designated here). Figs. 1-3

Description. See Magnusson (1947); Sheard (2004). Discussion. Characters separating Rinodina hallii from $R$. lindingeri: Thallus thin and smooth, often becoming thicker with age, rugose and rimose to rimose-areolate; apothecia lecideine but always containing at least some algal cells in the exciple (= pseudolecanorine) or apparently lecanorine, i.e., surrounded by a thalline collar, adnate; proper margin normally thin, often paler than the disc; proper exciple entirely colorless or pale brown in the outermost part; hypothecium colorless to yellowish, never deep brown (Table 1).

Chemistry. Zeorin [major] and variolaric acid [major]. Hypostictic acid [minor] was also detected in the specimen Boom 29426. Besides the lectotype, all specimens mentioned below were analysed by HPLC except that from $\mathrm{BCN}$.

Ecology and distribution. Mostly on deciduous trees but also on conifers, at elevations of 395-

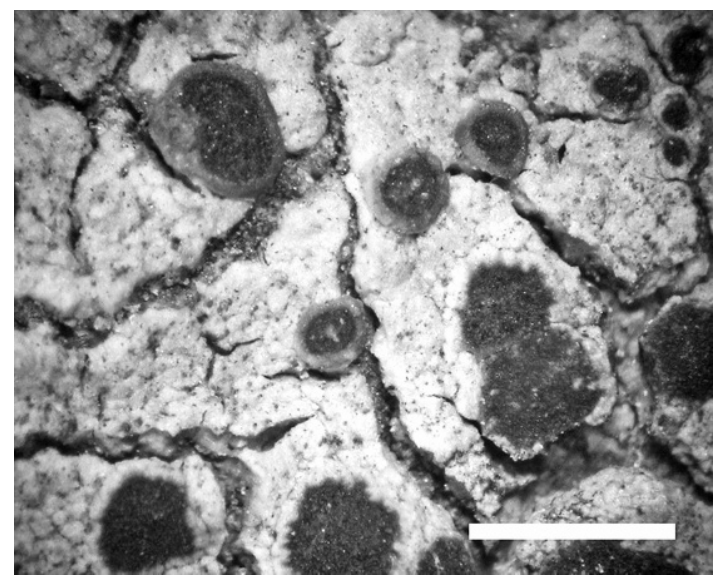

Figure 2. Thallus with lecideine and apparently lecanorine apothecia (surrounded by a thalline collar) of Rinodina hallii (ASU 516301). Scale $=1 \mathrm{~mm}$.

1675 m. A North American endemic species with an oceanic distribution (Sheard 2004).

Additional specimens examined. CANADA. BRITISH COLUmbia: Vancouver Island, Sidney, on maples, 19 November 1912, Macoun (Herbarium of G.K. Merrill, FH-259426, sub Rinodina exigua var. pruinosa Merrill). U.S.A. CALIFORNIA: upon redwood and oak (Quercus sonomensis), 1864 \& 1865, Bolander-A, 239, 163 (Tuck. Herb. Exs. 2117, FH!259422 259423, 259424, syntypes); Los Angeles Co., San Clemente Island, W-trending canyon running seaward toward Lost Point, W slope just NW of Thirst, ca. $1500 \mathrm{ft}$., the first large canyon $\mathrm{N}$ of the main largest canyon, 1966, Weber \& Santesson (BCN);

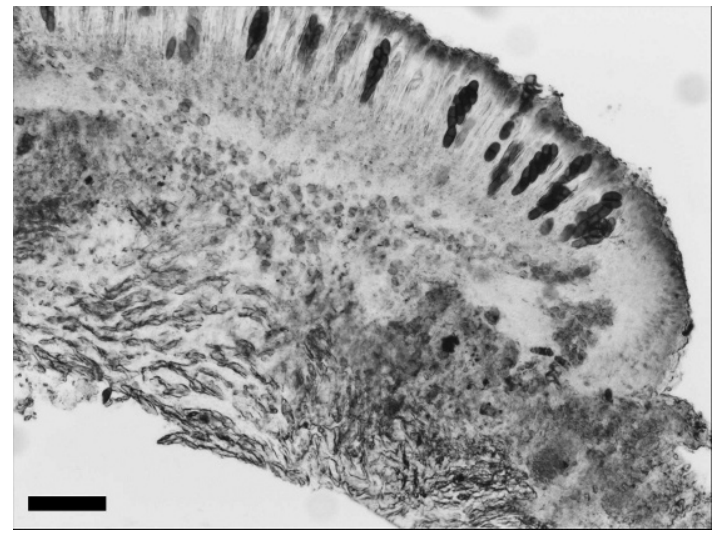

Figure 3. Section of an apothecium of Rinodina hallii showing the colorless proper exciple containing algal cells and the colorless hypothecium (ASU 516301). Scale $=75 \mu \mathrm{m}$. 
Table 1. Characters separating Rinodina hallii from $R$. lindingeri.

\begin{tabular}{|c|c|c|c|c|c|c|}
\hline & Thallus & Apothecia & Proper margin & Proper exciple & Hypothecium & Chemistry \\
\hline R. hallii & $\begin{array}{l}\text { Becoming rugose, } \\
\text { rimose to } \\
\text { rimose- } \\
\text { areolate }\end{array}$ & $\begin{array}{l}\text { Lecideine, } \\
\text { pseudolecanorine } \\
\text { or apparently } \\
\text { lecanorine, } \\
\text { immersed to } \\
\text { adnate }\end{array}$ & $\begin{array}{l}\text { Normally thin } \\
\text { and paler } \\
\text { than the } \\
\text { disc }\end{array}$ & $\begin{array}{l}\text { Colorless } \\
\text { entirely to } \\
\text { pale brown } \\
\text { in the } \\
\text { outermost } \\
\text { part }\end{array}$ & $\begin{array}{r}\text { Colorless to } \\
\text { yellowish }\end{array}$ & $\begin{array}{l}\text { Variolaric, zeorin } \\
\text { (majors); } \\
\text { hypostictic } \\
\text { acid normally } \\
\text { absent }\end{array}$ \\
\hline R. lindingeri & $\begin{array}{l}\text { Persistently } \\
\text { smooth to } \\
\text { slightly } \\
\text { rimose }\end{array}$ & Lecideine, sessile & $\begin{array}{l}\text { Thick and } \\
\text { prominent, } \\
\pm \text { concolorous } \\
\text { with disc }\end{array}$ & $\begin{array}{l}\text { Dark reddish } \\
\text { brown } \\
\text { entirely or } \\
\text { in major } \\
\text { part }\end{array}$ & $\begin{array}{c}\text { Dark brown, at } \\
\text { least in the } \\
\text { lower part }\end{array}$ & $\begin{array}{l}\text { Hypostictic acid, } \\
\text { zeorin } \\
\text { (majors); } \\
\text { variolaric } \\
\text { (minor) }\end{array}$ \\
\hline
\end{tabular}

Monterey Co., S of Carmel, S of Big Sur, Pfeiffer Big Sur State Park, "Quercus trail" with mature Quercus agrifolia, on Quercus, $121^{\circ} 46.6^{\prime} \mathrm{W}, 36^{\circ} 14.8^{\prime} \mathrm{N}, 30 \mathrm{~m}$, 2002, P. \& B. v.d. Boom (нв. воом 29426), between Big Sur and Morro Bay, Nacimiento, near crossing south coast/north coast trail, W sloping Quercus forest, on Q. agrifolia, $121^{\circ} 27.1^{\prime} \mathrm{W}, 36^{\circ} 00.6^{\prime} \mathrm{N}$, $840 \mathrm{~m}, 2002$, P. \& B. v.d. Boom (нв. воом 29460), Hastings Ecological Preserve, near cabin and spring on road above Jean Knop's study site, forest with maples, $36^{\circ} 21^{\prime} 45^{\prime \prime} \mathrm{N}, 121^{\circ} 34^{\prime} 0^{\prime \prime} \mathrm{W}$, ca. $800 \mathrm{~m}, 1989$, Ryan 27113 (ASU 527901); Santa Barbara Co., Santa Cruz Island, $7 \mathrm{~km}$ SSE of Prisoner's Harbor along road to the navy radar station, live oak stand, on $Q$. agrifolia, $34^{\circ} 0^{\prime} 0^{\prime \prime} \mathrm{N}, 119^{\circ} 40^{\prime} 30^{\prime \prime} \mathrm{W}$, ca. $335 \mathrm{~m}, 1994$, Nash III 32515a (ASU 527965a); Santa Clara Co., near Saratoga Gap at Skyline Blvd., just SW of San Jose,

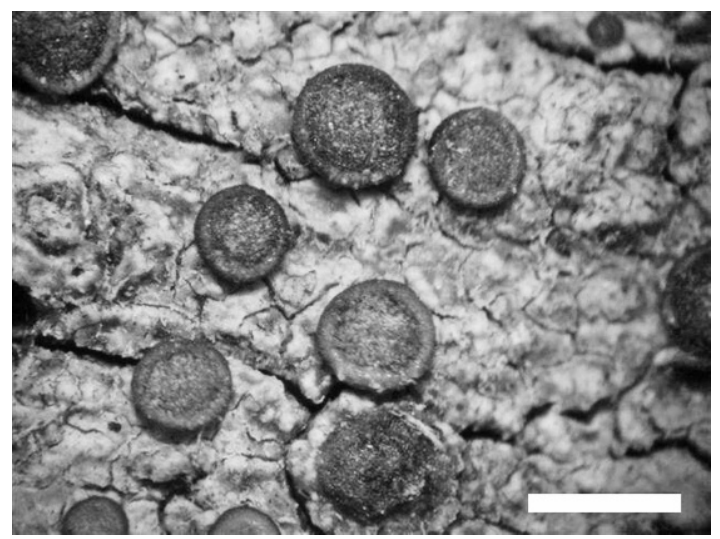

Figure 4. Thallus slightly rimose with sessile, lecideine apothecia with prominent proper margins and pruinose discs of Rinodina lindingeri (v.d. Boom 38157). Scale $=1 \mathrm{~mm}$. ca. 300 m, 1974, Sigal 169 (ASU 516301); San Luis Obispo Co., $16 \mathrm{~km}$ E of San Simeon along route 46, on Quercus, ca. 90 m, 1973, Nash III 8142a (AsU 526294). OREGON: Benton Co., above Road 720 above Sulphur Springs McDonald-Dunn Forest just NW of Corvallis, $44^{\circ} 38^{\prime} 54^{\prime \prime} \mathrm{N}, 123^{\circ} 19^{\prime} 24^{\prime \prime} \mathrm{W}$, ca. $309 \mathrm{~m}$, 2000, McCune 25747 (Asu 505197).

Rinodina lindingeri (Erichsen) Giralt \& van den Boom comb. nov.; Buellia lindingeri Erichsen, Hedwigia 66: 281. 1926. Type: Macaronesia. CANARy Islands. Tenerife: Mesa Gallardina near La Laguna, on Agave americana, 750 m, 1917, L. Lindinger (HB!; holotype). Figs. 4, 5

Description. See Giralt and Matzer (1994); Kalb \& Hafellner (1992); Tavares (1952).

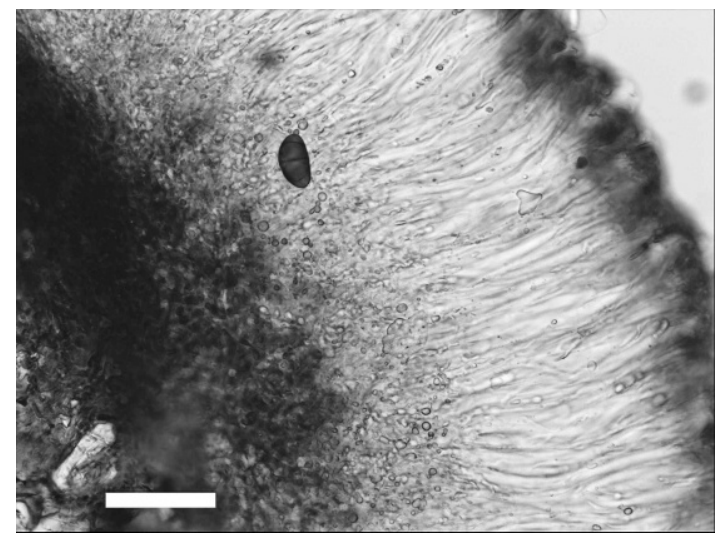

Figure 5. Section of an apothecium of Rinodina lindingeri showing the brown lower part of the hypothecium with abundant oil droplets and the hymenium with oil paraphyses (v.d. Boom 38193). Scale $=50 \mu \mathrm{m}$. 
Discussion. Characters separating Rinodina lindingeri from $R$. hallii: Thallus persistently smooth to slightly rimose; apothecia lecideine, sessile and constricted at the base; proper margin thick and prominent, \pm concolorous with the disc; proper exciple entirely or in part dark reddish brown; hypothecium, at least in the lower part, dark brown (Table 1).

Chemistry. Hypostictic acid [major (minor in Brand 13503)], zeorin [major] and variolaric acid [minor (major in Brand 13503]. Arthothelin [minor], 4-O-methylhypoprotocetraric acid [trace] and hypostictolide [trace] were also detected in the specimens Boom 22459 and Boom 38193. All specimens mentioned below were analysed by HPLC.

Ecology and distribution. Mainly on smooth bark of broad leaved trees, but also on conifers or wood, at moderate altitudes (500-1100 m), in the laurel forest zone. Rinodina lindingeri is only known from Macaronesia (Canary Islands and Madeira).

Additional specimens examined not reported in Giralt and Matzer (1994). MACARONESIA. CANARY IsLANDS. LA PALMA: $8 \mathrm{~km} \mathrm{~N}$ of Santa Cruz, Bco. La Galga, Cubo de la Galga, Laurisilva forest in cleft with volcanic rock, on Sorbus(?), $28^{\circ} 45.5^{\prime} \mathrm{N}$, $17^{\circ} 46.7^{\prime} \mathrm{W}, 550 \mathrm{~m}, 1999$, v.d. Boom (нв. воом 22459); 2.2 km WSW of La Galga, Bco. La Galga, 28.7/84.5 FN 28E, on branches of fallen mature Persea indica in wood in cleft, 525 m, 1986, Brand (HB. BRAND 13352); Cumbre Nueva, W side, $S$ of tunnel, 23.4/71.2, FN56, on Castanea in orchard on W-slope, 1120 m, 1986, Brand (HB. BRAND 13503). TENERIFE: N of Santiago del Teide, 1.5-2.5 km WSW of Erjos, open path to Las Portelas, in laurisilva, with a.o. Laurus azorica, Erica arborea, Apollonias barbujana, some shrubs and outcrops, including a by-path young shrubs and trees and well-lit outcrops, on Laurus, $1050 \mathrm{~m}, 28^{\circ} 19.49^{\prime} \mathrm{N}, 16^{\circ} 43.84^{\prime} \mathrm{W}, 2007$, P. \& B. v.d. Boom (нв. воом 38193).

\section{Discussion}

Morphologically, Rinodina lindingeri and $R$. hallii differ mainly in the apothecium-type and development and in the color of the hypothecium. In $R$. lindingeri the apothecia are truly lecideine at all ontogenic stages, without any algal cell in the proper exciple. They are sessile, with a thick and prominent proper margin that is concolorous with the disc, and the hypothecium is, at least in the lower part, dark brown. In $R$. hallii the apothecia are apparently lecideine but always contain at least some algal cells in the proper exciple (= pseudolecanorine). They are adnate, with a thin proper margin often paler than the disc and the hypothecium is hyaline to yellowish. Further, in $R$. hallii the apothecia are sometimes apparently lecanorine since a thalline collar plenty of algal cells surrounds them. This character was noted by Tuckerman who wrote in the sheet of the type specimen "apothecia plus minus thallo coronata".

Otherwise the taxa are morphologically identical: thallus crustose, continuous, usually well delimited by a dark brown, \pm dendritic prothallus; algal cells small, to $10 \mu \mathrm{m}$ in diam., often in clusters; disc \pm dark brownish violet, covered or not by a whitish pruina; brown pigment in epihymenium, exciple and hypothecium reacting $\mathrm{K}+$ olivaceous; hymenium colorless, lacking oil droplets but with abundant oil paraphyses; hypothecium with oil droplets; asci Lecanora-type, 8-spored; ascospores large, Physciatype, 20-30 $\times 9-12 \mu \mathrm{m}$, with torus, microrugulate (visible at $1000 \times$ ), developing after an ontogeny of type A; and conidia bacilliform, 4-6 × 1-1.5 $\mu \mathrm{m}$.

Two additional interesting characters shared by these two taxa are found in the anatomy of the proper exciple and the epihymenium. The proper exciple is very thick, prosoplectenchymatic, anatomically uniform throughout (not differentiated into an inner and an outer part), composed of moderately thick-walled ( $=$ mesodermatous) hyphae, interwoven, thickly packed, \pm radially oriented, with colorless to brown cell-walls. However, the exciples and hypothecia of the two species differ in their pigmentation. In $R$. lindingeri, the proper exciple may be entirely dark reddish brown; dark reddish brown except in the innermost part; or, very rarely, only pigmented in the outermost part. The more extended the dark reddish brown pigmentation of the proper exciple, the more the dark brown pigmentation of the hypothecium extends into the hymenium. By contrast, in the pseudolecanorine apothecia of $R$. hallii the proper exciple is entirely colorless or only pale brown pigmented in the outermost part, and the hypothecium is colorless to yellowish, never deep brown. 
Surrounding the proper exciple of the lecideine apothecia of $B$. lindingeri and the pseudolecanorine apothecia of $R$. hallii, there is an additional, \pm thick layer of loosely packed, mesodermatous, colorless to rarely pale brown hyphae immersed in a gelatinous extracellular matrix. This additional layer of hyphae corresponds macroscopically to a \pm visible whitish 'collar' surrounding at least the basal part of the proper margin of both species. This layer of hyphae or collar is very well developed and includes many algal in $R$. hallii whereas, in contrast, is less developed and lacks algal cells in $R$. lindingeri.

The epihymenium is formed by richly branched and interwoven paraphyses with not or only slightly enlarged, colorless to pale brown pigmented apical cells. It is always covered by a more or less abundant, coarsely granular, brownish orange epipsamma (crystals) that dissolves in K. Anatomically the epihymenium intergrades into a true epithecium since it forms a more or less separate layer of hyphae on top of the hymenium (Kalb \& Hafellner 1992; Rambold et al. 1994).

Chemically, both species are also very similar. They contain zeorin and variolaric acid, always accompanied in $R$. lindingeri by hypostictic acid, a secondary substance only once detected in $R$. hallii. The combination of zeorin, hypostictic and variolaric acids is unique within Buellia and Rinodina.

However, variolaric acid is also found in the terricolous R. mniaraea (Ach.) Körb. and R. turfacea (Wahlenb.) Körb. (and related taxa) and hypostictic acid in some Mediterranean populations of the silicicolous R. luridescens (Anzi) Arnold (according to Mayrhofer \& Moberg [2002]). These terricolous species have large Physcia-type ascospores like $R$. lindingeri and $R$. hallii, while $R$. luridescens has pseudolecanorine apothecia and a \pm brownish pigmented hypothecium. According to Sheard (2004), R. hallii may be related to R. trevisanii (Hepp.) Körb., a species belonging to the R. archaeagroup with Physconia-type ascospores and that contains zeorin.

Among Buellia s. lat., hypostictic acid is known in B. sequax (Nyl.) Zahlbr. aggr., B. frigida Darb. and B. subfrigida May (see Giralt et al. 2000, under B. erubescens Arnold), B. argillicola de Lesd., B. mamillana (Tuck.) W.A. Weber and B. spuria
(Schaer.) Anzi (Bungartz et al. 2007). These Buellia species have no others characters in common with $R$. lindingeri and $R$. hallii.

Several authors (Giralt \& Matzer 1994; Kalb \& Hafellner 1992; Rambold et al. 1994) have already commented on the uncertain taxonomic position of "Buellia" lindingeri. Its taxonomic assignment is controversial because it exhibits characters that exclude it from both Buellia (the Lecanora-type asci) and Rinodina (the lecideine apothecia and the brown hypothecium). An additional extraneous feature present in this species is its epithecium. In contrast, there has been no discussion to include $R$. hallii in Rinodina, probably due to its apothecia that are pseudolecanorine (always containing algal cells) or even apparently lecanorine and its colorless hypothecium, both characters fitting properly with the generic concept of Rinodina. Thus, in R. hallii the only foreign element to Rinodina constitutes its epithecium. This epithecium as well as several other characters (secondary chemistry, color and pruinosity of the apothecial discs,

prosoplectenchymatic proper exciple, oil paraphyses, ascospore-type and size, ascospore-ontogeny and bacilliform conidia) are shared by $R$. hallii and $R$. lindingeri, again emphasizing that both species are closely related.

Due to the presence of a true epithecium, Kalb and Hafellner (1992) stated that B. lindingeri might be related to still unsettled taxa from the tropics. However, in Marbach's (2000) monographic treatment of the corticolous/lignicolous species of Buellia s. lat. from subtropical and tropical areas, no taxon is mentioned possessing a true epithecium or other characters that could relate it with $R$. lindingeri and R. hallii. According to Etayo and Marbach (2003) all species of Hafellia have ".... strongly branched paraphyses (forming an epithecium)....” In contrast, Bungartz (2004) affirms that the paraphyses of the genus Hafellia are not considerably different from other Buellia s. lat. species and a distinct layer on the surface of the hymenium cannot be observed (i.e., a distinct epithecium is absent). In any case, the two main diagnostic characters of the genus Hafellia (hymenium inspersed with oil droplets and Callispora-type ascospores) are absent in R. hallii and R. lindingeri. 
Among the genera newly erected or resurrected by Marbach (2000), only Sculptolumina has rinodinoid ascospores (with pronounced inner wall thickenings). However, Sculptolumina has a hymenium inspersed with oil droplets, a poorly developed proper exciple composed of \pm carbonized cells and long filiform conidia (Giralt et al. 2009). Although all the genera treated in Marbach (2000) probably have Bacidia-type asci, this cannot be confirmed because the author does not distinguish between Bacidia and Lecanora-type asci and includes both ascus-types into the Physciaceae-type.

Although $R$. lindingeri and $R$. hallii seem to occupy an isolated position within Buellia or Rinodina we could find no evidence strong enough to accommodate them within a new, separate genus of the Physciaceae. Nevertheless, as molecular studies exclude B. lindingeri from the Buellia-group (Molina et al. 2002; Crespo et al. 2004) and relate it with the Physcia-group (Wedin et al. 2002) — exactly with Rinodina lecanorina (Massal.) Massal. and $R$. luridescens (Grube \& Arup 2001; Grube \& Hawksworth 2007; Helms et al. 2003; Kaschik 2006) - we transfer Buellia lindingeri to the genus Rinodina. Unfortunately no genetic data are yet available for $R$. hallii.

The molecular results (see the references mentioned above) which indicate that $R$. lindingeri and $R$. lecanorina constitute a well-supported monophyletic group are unexpected to us. Morphologically, $R$. lecanorina is not at all similar to $R$. lindingeri and $R$. hallii. It has cryptolecanorine to lecanorine apothecia and Bicinta-type ascospores. Chemically, it contains zeorin, as do many other Rinodina species. A monophyletic relation with $R$. luridescens appears more plausible because this is a species also characterized by pseudolecanorine apothecia, with a brown, well-developed proper exciple, a brownish hypothecium, rather large ascospores that are intermediate between the Milvinaand the Physconia-type (close to the Physcia-type) and a thallus that often contains hypostictic acid.

\section{ACKNOWLEDGMENTS}

The authors are indebted to M. Brand and the herbaria ASU, BCN and $\mathrm{FH}$ for the loan of specimens used in this study, to Mercedes Barbero for carrying out some TLC analyses, and to Harrie Sipman for critical reading of the manuscript. We also wish to thank F. Bungartz and J.W. Sheard for their valuable reviews. The first author thanks the Comissionat per a la Recerca (Catalan Government) and the project CGL2007-66734-C0302/BOS (Spanish Government) for financial support.

\section{Literature Cited}

Boom van den, P. P. G., M. Giralt \& J. Etayo. 2009. Notes on the lichen genus Rinodina from the Canary Islands. Nova Hedwigia 88: 423-440.

Bungartz, F. 2004. New and previously unrecorded saxicolous species of Buellia s. lat. with one-septate ascospores from the Greater Sonoran Desert Region. Mycotaxon 90: 81-123.

—, A. Nordin \& U. Grube. 2007. Buellia De Not.

Pages 113-179. In T. H. Nash III, B. D. Ryan, P. Diederich, C. Gries \& F. Bungartz (eds.), Lichen Flora of the Greater Sonoran Desert Region. Volume 3. Lichens Unlimited, Tempe, AZ.

Crespo, A., O. Blanco, X. Llimona, Z. Ferencová \& D. L. Hawksworth. 2004. Coscinocladium, an overlooked endemic and monotypic Mediterranean lichen genus of Physciaceae, reinstated by molecular phylogenetic analysis. Taxon 53 : 405-414.

Dughi, R. 1952. Un problème de lichénologie non résolu: L'origine et la signification de l'apothécie lécanorine. Annales de la Faculté des Sciences de Marseille, Sér. 2, 21: 219-243.

Elix, J. A., M. Giralt \& J. H. Wardlaw. 2003. New chlorodepsides from the lichen Dimelaena radiata. Bibliotheca Lichenologica 86: 1-7.

Etayo, J. \& B. Marbach. 2003. Hafellia alisioae and Hafellia gomerana (lichenized Ascomycetes, Physciaceae), two new species from the Canary Islands, with a key to all known corticolous species. Lichenologist 35: 369-375.

Giralt, M. 2001. The lichen genera Rinodina and Rinodinella (lichenized Ascomycetes, Physciaceae) in the Iberian Peninsula. Bibliotheca Lichenologica 79: 1-160.

\& M. Matzer. 1994. The corticolous species of the genus Rinodina with biatorine or lecideine apothecia in southern Europe and Macaronesia. Lichenologist 26: 319-332.

— M. Barbero \& J. A. Elix. 2000. Notes on some corticolous and lignicolous Buellia species from the Iberian Peninsula. Lichenologist 32: 105-128.

— , G. Paz-Bermúdez \& J. A. Elix. 2009. New data on Sculptolumina japonica (Physciaceae). The Bryologist 112: 397-407.

Grube, M. \& U. Arup. 2001. Molecular and morphological evolution in Physciaceae (Lecanorales, lichenized Ascomycetes), with special emphasis on the genus Rinodina. Lichenologist 33: 63-72.

\& D. L. Hawksworth. 2007. Trouble with lichen: the reevaluation and re-interpretation of thallus form and fruit body types in the molecular era. Mycological Research 11: 1116-1132. 
Hafellner, J. 1995. A new check-list of lichens and lichenicolous fungi of insular Laurimacaronesia including a lichenological bibliography for the area. Fritschiana 5: 1-132.

2002. Additions and corrections to the checklist and bibliography of lichens and lichenicolous fungi of insular Laurimacaronesia. II. Fritschiana 36: 1-10.

2005. Additions and corrections to the checklist and bibliography of lichens and lichenicolous fungi of insular Laurimacaronesia. III. Fritschiana 49: 1-13.

Helms, G., T. Friedl \& G. Rambold. 2003. Phylogenetic relationships of the Physciaceae inferred from rDNA sequence data and selected phenotypic characters. Mycologia 95: 1078-1099.

Hernández-Padrón, C. 1987. Flora y vegetación liquénica epífita de los Sabinares Herreños. Biblioteca Lichenologica 27: 1-317.

2001. División lichenes y lichenicolous fungi.

Pages 88-97. In I. Izquierdo, J. L. Martín, N. Zurita \& M. Arechavaleta (eds.), Lista de Especies Silvestres de Canarias (Hongos, Plantas y Animales Terrestres) 2001. Consejería de Política Territorial y Medio Ambiente, Gobierno de Canarias, La Laguna.

Kalb, K. \& J. Hafellner. 1992. Bemerkenswerte Flechten und lichenicole Pilze von der Insel Madeira. Herzogia 9: 45-102.

Kaschik, M. 2006. Taxonomic studies on saxicolous species of the genus Rinodina (lichenized ascomycetes, Physciaceae) in the Southern Hemisphere with special emphasis in Australia and New Zealand. Bibliotheca Lichenologica 93: $1-162$.
Magnusson, A. H. 1947. On North-American, non-saxicolous species of the genus Rinodina. Botaniska Notiser 1947: 32-54.

Marbach, B. 2000. Corticole und lignicole Arten der Flechtengattung Buellia sensu lato in den Subtropen und Tropen. Bibliotheca Lichenologica 74: 1-384.

Mayrhofer, H. \& R. Moberg. 2002. Rinodina. Nordic Lichen Flora 2: 7-9.

Molina, M. C., A. Crespo, O. Blanco, N. Hladun \& D. L. Hawksworth. 2002. Molecular phylogeny and status of Diploicia and Diplotomma, with observations on Diploicia subcanescens and Diplotomma rivas-martinezii. Lichenologist 34: 509-519.

Rambold, G., H. Mayrhofer \& M. Matzer. 1994. On the ascus types in the Physciaceae (Lecanorales). Plant Systematics and Evolution 192: 31-40.

Sheard, J. W. 2004. Rinodina. Pages 457-492. In T. H. Nash III, B. D. Ryan, P. Diederich, C. Gries \& F. Bungartz (eds.), Lichen Flora of the Greater Sonoran Desert Region. Volume 2. Lichens Unlimited, Tempe, AZ.

Tavares, C. N. 1952. Contribution to the lichen flora of Macaronesia. I. Lichens from Madeira. Portugalia Acta Biologica. Ser. B, Sistemática, Ecologia, Biogeografia e Paleontologia 3: 308-391.

Wedin, M., E. Baloch \& M. Grube. 2002. Parsimony analyses of mtSSU and nITS rDNA sequences reveal the natural relationships of the lichen families Physciaceae and Caliciaceae. Taxon 51: 655-660.

ms. received December 9, 2008; accepted August 10, 2009. 